\title{
Occurrence and seasonality of Vibrio aestuarianus in sediment and Crassostrea gigas haemolymph at two oyster farms in France
}

\author{
Afi Azandégbé ${ }^{1}$, Matthieu Garnier ${ }^{1}$, Françoise Andrieux-Loyer ${ }^{2}$, Roger Kérouel ${ }^{2}$, \\ Xavier Philippon ${ }^{2}$, Jean-Louis Nicolas ${ }^{1, *}$
}

${ }^{1}$ Laboratoire de physiologie des Invertébrés, PFOM, and ${ }^{2}$ Laboratoire Dyneco, IFREMER, Centre de Brest BP70, 29280 Plouzané, France

\begin{abstract}
Vibrio aestuarianus is frequently found in coastal areas and can infect and induce mortalities in the pacific oyster Crassostrea gigas. However, nothing is known about its distribution and seasonality in the estuarine environment, especially where oyster farming is practiced. Its occurrence was investigated in sediment and oyster haemolymph at 2 oyster farms in Brittany (France) over 2 yr during 2 periods, from June to September 2007 and from February to June 2008. Total heterotrophic bacteria (HB) were cultured on marine agar while total Vibrio spp. and V. aestuarianus were selectively numerated using thiosulfate citrate bile salts sucrose agar (TCBS agar) and the species-specific hybridisation method, respectively. PCR was performed to detect $V$. aestuarianus in sediment when it became unculturable. Both total Vibrio spp. and $V$. aestuarianus had a seasonal trend. The highest concentrations were recovered in the warmest months. Its abundance ranged from $10^{2}$ to $4 \times 10^{5} \mathrm{CFU}$ $\mathrm{ml}^{-1}$ in haemolymph and from $10^{3}$ to $1 \times 10^{4} \mathrm{CFU} \mathrm{g}^{-1}$ in the sediment. Temperature was the main factor influencing the concentration of Vibrio spp. and $V$. aestuarianus in the sediment. Thus $V$. aestuarianus might subsist during the cold seasons in the sediment, from which it can emerge when environmental conditions became favourable.
\end{abstract}

KEY WORDS: Vibrio aestuarianus $\cdot$ Crassostrea gigas $\cdot$ Sediment $\cdot$ Seasonal abundance $\cdot$ Colony-blot Resale or republication not permitted without written consent of the publisher

\section{INTRODUCTION}

Pacific oysters have suffered irregularly from summer mortalities for the last $10 \mathrm{yr}$ in France. This has concerned mainly juveniles from 3 to 18 mo of age. A multidisciplinary study was conducted (2001 to 2006) to identify causes of these mortalities (Samain \& McCombie 2008). The disease was characterised by a complex syndrome that depended on several factors including the physiological status of the oysters, pathogens such as the herpes virus and some Vibrio species, and environmental factors such as temperature, phytoplankton abundance, and sediment. Experiments demonstrated that the proximity of oysters to the sediment increased mortalities. This impact of sediment may be caused by the release of toxic substances and/or the presence of pathogens. High concentrations of the herpes virus in oyster tissues explained about $50 \%$ of the mortalities until summer 2008, when its prevalence reached around $90 \%$ in moribund oysters. Septicaemic Vibrio spp. including $V$. splendidus and $V$. aestuarianus have also been frequently isolated in moribund oysters in the field during summer mortalities, as well as in hatcheries and nurseries. The prevalence of $V$. aestuarianus reached about $56 \%$ (Garnier et al. 2007) until the mortality events of 2008 and 2009. It can be considered as a pathogen since the experimental infection was reproduced by injection, as well as by bathing (Garnier et al. 2008).

Investigations of the mechanism of Vibrio aestuarianus infection led to the identification of a zinc-dependent metalloprotease (Vam) implicated in the virulence of this bacterium since it notably reduces haemocyte efficiency in oysters (Labreuche et al. 2006). The gene of 
this protease was detected in the most of $V$. aestuarianus strains (Y. Labreuche unpubl. data) whatever their virulence. Recently, taking into account its virulence and other phenotypic traits specifically found in French isolates, 2 subspecies were created: $V$. aestuarianus subsp. aestuarianus and $V$. aestuarianus subsp. francensis (Garnier et al. 2008). Moreover, a great heterogeneity in virulence was demonstrated among the $V$. aestuarianus subsp. francensis strains.

Therefore, more attention has been paid to the role of Vibrio aestuarianus as a significant Crassostrea gigas pathogenic agent. However, few studies have been undertaken concerning the environmental behaviour of either $V$. aestuarianus or any other Vibrio species pathogenic for marine invertebrates.

Ecological studies would be very useful for identifying the environmental sources of these Vibrio spp. and for understanding how they infect their host, so that appropriate measures can be taken to prevent or limit the infection. The ecology of some human pathogenic Vibrio spp. (V. cholerae, V. parahaemolyticus, V. vulnificus) has been extensively studied (Eiler \& Bertilsson 2006, Eiler et al. 2007), mainly in seawater, and some reports (Pfeffer et al. 2003, Fukushima \& Seki 2004) are available on the Vibrio populations in the environment. These populations can be found in seawater, shellfish, fish, and sediment. Pathogenic Vibrio spp. are generally found mixed with innocuous Vibrio spp. However, each Vibrio species may have a particular behaviour and must be specifically traced to discover its ecological niches. In the present study, we investigated the presence and abundance of V. aestuarianus in relationship with environmental parameters in sediment and oyster haemolymph over 2 yr on 2 oyster farms in France.

\section{MATERIALS AND METHODS}

Sampling sites. Sampling was conducted at Fort Espagnol in Rivière d'Auray $\left(47^{\circ} 36^{\prime} \mathrm{N}, 2^{\circ} 58^{\prime} \mathrm{W}\right)$ and Viviers Beg Ar Vill in Aber Benoît $\left(48^{\circ} 36^{\prime} \mathrm{N}, 4^{\circ} 36^{\prime} \mathrm{W}\right)$, 2 estuarine regions in France where oyster farming is highly developed. The Rivière d'Auray represents the west part of the Gulf of Morbihan in south Brittany. The Rivière d'Auray contains 11.75 million $\mathrm{m}^{3}$ of seawater. The tidal range is between $4.5 \mathrm{~m}$ (upstream) and $5 \mathrm{~m}$ (downstream). The tidal flux causes a renewal of $50 \%$ of the Gulf's water every 10 d (20 tides).

Aber Benoît is an $8 \mathrm{~km}$ long estuary river situated in northwest Finistère in Brittany. The average water flow is about $0.418 \mathrm{~m}^{3} \mathrm{~s}^{-1}$. The major part of the river consists of a basin of $12 \mathrm{~km}$ long with $14 \mathrm{~km}^{2}$ of surface and open to the sea. Both sites are subjected to terrestrial influences through catchment areas of moderate surface and are convenient for breeding oysters due to the presence of phytoplankton blooms (Fig. 1).

Sample collection. Three bags containing $2502 \mathrm{yr}$ old oysters were laid on $50 \mathrm{~cm}$ high tables at each sample site. Sampling was performed once each month at low tide in 2007 (June, July, August, and September) and in 2008 (February, March, May, and June). At both sites and on each date, 10 oysters were randomly sampled per bag and 3 replicates of sediment (5 $\mathrm{cm}$ depth) were taken with a $50 \mathrm{ml}$ plastic tube (Polypropylene centrifuge tube; Falcon) below the oyster tables, and 3 others were sampled $30 \mathrm{~m}$ away from the tables. Water temperature and salinity were measured on site with a salinometer (WTW LF340-B). The pH was also monitored using a $\mathrm{pH}$ meter (WTW $\mathrm{pH} 340$ ).

Sample treatment. For each site, the sediment samples $(2 \times 3$ replicates $)$ and the oyster samples $(3 \times 10)$ were processed within $12 \mathrm{~h}$ of collection, following aseptic techniques. Haemolymph was extracted from the oysters using a $1 \mathrm{ml}$ plastic syringe and stored individually in micro-tubes. Each haemolymph sample was observed with an optical microscope to check the presence of haemocytes before dilution.

Ten grams of each sediment sample were suspended in $10 \mathrm{ml}$ of sterile filtrated seawater, homogenized by vortexing for $5 \mathrm{~min}$, and the supernatants were diluted 1000-fold in seawater.

Both sediment and haemolymph dilutions were spread-plated on marine agar (Difco) for culturable heterotrophic bacteria (HB) counts. Vibrio aestuarianus was enumerated by colony-blot hybridization. Marine agar is commonly used for the non-selective cultivation and isolation of marine bacteria. $V$. aestuarianus grew on this medium within $48 \mathrm{~h}$ at $20^{\circ} \mathrm{C}$. Using longer periods of incubation resulted in swarming colonies, which decreased the accuracy of $V$. aestuarianus counts. Consequently, culturable heterotrophic colonies were counted after incubation for $48 \mathrm{~h}$ at $20^{\circ} \mathrm{C}$ before performing the colony blot hybridisation for $V$. aestuarianus.

Thiosulfate citrate bile salts sucrose agar (TCBS agar; Difco) was used for culturable Vibrio populations. This medium is used to isolate and cultivate the major Vibrio populations even if some strains, including $V$. aestuarianus, cannot grow on it. Colonies were counted after incubation for $48 \mathrm{~h}$ at $20^{\circ} \mathrm{C}$.

Digoxygenase-labelled probe and colony-blot hybridization. The specific count of Vibrio aestuarianus was determined by a hybridisation technique, using a specific $V$. aestuarianus $176 \mathrm{bp}$ fragment probe targeting the gyrB gene of this Vibrio species, on marine agar isolates. In silico, this fragment had $94 \%$ similarity with the closest species, V. pacinii (AB298264), and 82\% with V. splendidus (AJ577824). The digoxygenin-labelled probe was then PCR amplified with the following oligonucleotide sequences: 


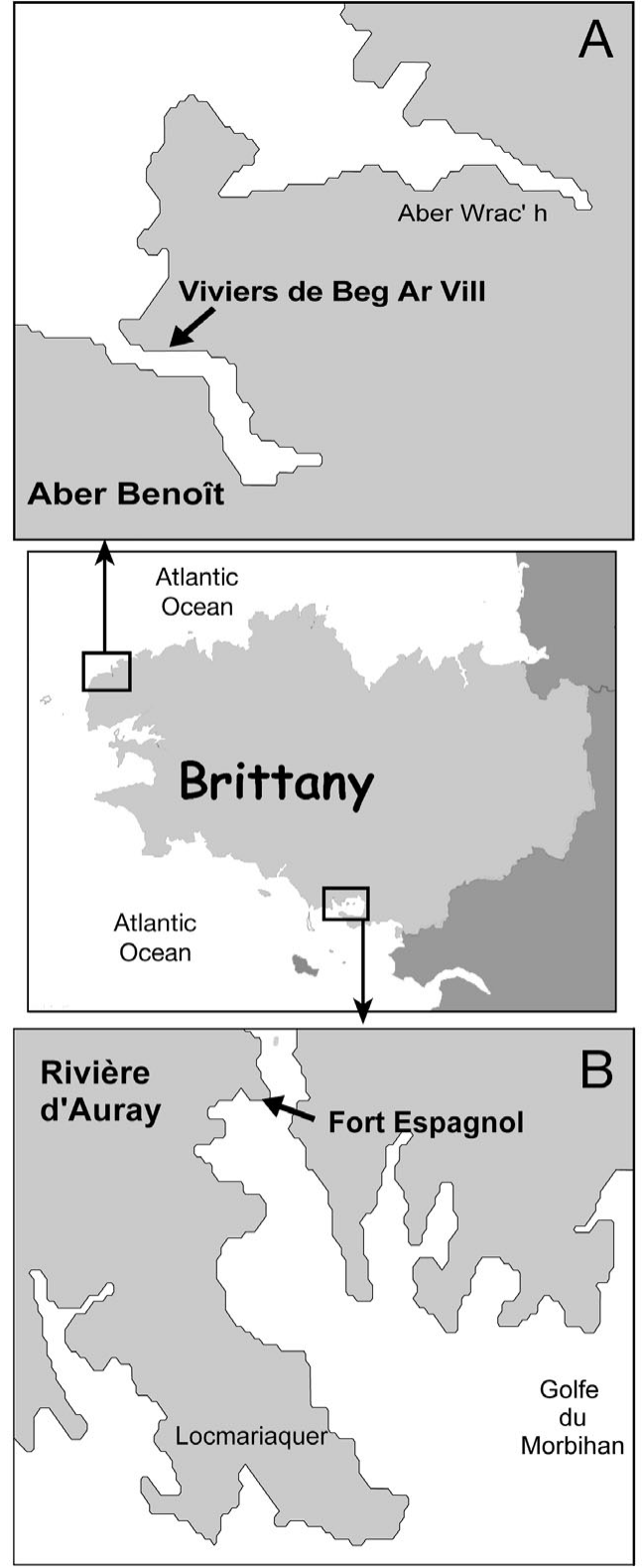

Fig. 1. (A) Aber-Benoît and (B) Rivière d'Auray in the gulf of Morbihan. Locations of sampling sites are indicated by arrows

Vaest gyrdir (positions 307 to 330): 5'-TCT TTC CTA AAC TCT GGC GTA TGC-3' and Vaest gyrrev3 (positions 459 to 482): 5'-ATG CCA TCT TCT TCA CGA GTG TGG- 3' by using the DIG high prime DNA labeling and detection starter kit I (Roche Applied Science). Specificity was demonstrated by colony hybridization using culture collection strains of $V$. aestuarianus and other related Vibrio species.

Colony blots were prepared from bacteria growing on marine agar for $48 \mathrm{~h}$ at $20^{\circ} \mathrm{C}$. First, the plates were incubated for $30 \mathrm{~min}$ at $4^{\circ} \mathrm{C}$. Colonies were transferred to a nylon membrane (Hybond ${ }^{\mathrm{TM}}-\mathrm{N}+$; GE Healthcare) by overlaying agar plates for 1 to $3 \mathrm{~min}$. Membranes were placed on Whatman paper saturated with denaturing buffer, and alkaline lysis with proteinase K treatment was carried out as previously described (Wright et al. 1993). Membranes were incubated for $2 \mathrm{~h}$ at $42^{\circ} \mathrm{C}$ in $12.5 \mathrm{ml}$ of hybridization buffer containing formamide (50\%) (Sigma Aldrich), saline sodium citrate (SSC) (5×) and sodium lauryl sulphate $(0.1 \%)$. Hybridization was done overnight at $42^{\circ} \mathrm{C}$, followed by membrane washing once in SSC $(2 \times)$ with sodium dodecyl sulphate (SDS) $(0.1 \%)$ for $15 \mathrm{~min}$ at room temperature and twice in $\operatorname{SSC}(0.5 \times)$ and $(0.1 \times)$ with $\operatorname{SDS}(0.1 \%)$ for $15 \mathrm{~min}$ at $65^{\circ} \mathrm{C}$. Alkaline phosphatase activity was assayed with nitroblue tetrazolium (Merck) $\left(0.3 \mathrm{mg} \mathrm{ml}^{-1}\right)$ and 5bromo-4-chloro-3-indolyl-phosphate (BCIP, Biochemica) $\left(0.2 \mathrm{mg} \mathrm{ml}^{-1}\right)$.

Sediment DNA extraction. To detect the presence of Vibrio aestuarianus in the sediment by PCR, DNA was extracted according to Zhou et al. (1996), with some slight modifications. DNA was extracted according to this SDS-based lysis method and was suspended in $500 \mu \mathrm{l}$ of sterile deionised water. Finally, the DNA was purified with the Wizard ${ }^{\circledR}$ DNA Clean-Up System (Promega) according to the manufacturer's instructions and was diluted to $10 \mathrm{ng} \mathrm{\mu l}^{-1}$ for PCR amplification.

Bacterial DNA extraction. Three colonies that were isolated from sediment and one of those isolated from oyster haemolymph after Vibrio aestuarianus-specific colony hybridization were grown for $24 \mathrm{~h}$ in marine broth and subjected to DNA extraction. Cells from the marine broth cultures were harvested and re-suspended in TE buffer $(10 \mathrm{mM}$ Tris-HCl, 1mM EDTA, $\mathrm{pH}$ 7.5). The cell pellets were treated with $1 \%$ SDS and proteinase $\mathrm{K}\left(100 \mu \mathrm{g} \mathrm{ml}^{-1}\right)$, incubated for $1 \mathrm{~h}$ at $55^{\circ} \mathrm{C}$, and then $\mathrm{NaCl}(0.7 \mathrm{M})$ was added. The aqueous phase was treated successively with phenol-chloroform and chloroform, respectively. The resulting DNA was precipitated with 0.6 volume of isopropanol, washed with $70 \%$ ethanol, air dried, and finally dissolved in Milli-Q water.

PCR amplification. To detect Vibrio aestuarianus in the sediments sampled in June to September 2007 and February 2008 for each site, $V$. aestuarianus specific PCR was performed by nested PCR with DNA directly extracted from the sediment. First, the 16S rDNA gene was amplified using the universal eubacterial primers, E8F and 1492R (Weisburg et al. 1991). Amplification was performed in a $25 \mu \mathrm{l}$ volume consisting of $10 \mathrm{ng}$ of sediment DNA, $2 \mu \mathrm{M}$ of each primer, $4 \mathrm{mM}$ dNTPs, $1.5 \mathrm{mM} \mathrm{MgCl}_{2}, 1 \mathrm{U}$ AmpliTaq DNA polymerase (Invitrogen Life Technologies) with its buffer and an appropriate volume of sterile Milli-Q water. The amplification was carried out in a thermal cycler (Biorad) with initial denaturation at $95^{\circ} \mathrm{C}$ for $5 \mathrm{~min}$, followed by 30 
cycles of amplification (denaturation at $95^{\circ} \mathrm{C}$ for $30 \mathrm{~s}$, annealing at $54^{\circ} \mathrm{C}$ for $1 \mathrm{~min}$, and extension at $72^{\circ} \mathrm{C}$ for $1 \mathrm{~min} 30 \mathrm{~s}$. Finally the samples were kept at $72^{\circ} \mathrm{C}$ for 7 min as the final extension. The PCR-amplified products were diluted 10 -fold, and a second PCR amplification was performed using $V$. aestuarianus 16S rDNA specific primers: Vaest 64-99 dir 5'-GAG CGG TTA CAT TTC AAA ACG TTG CTT TTG AAG ATG-3' and Vaest 664-683rev 5'-CCT CTA CAG TAC TCT AGT $\mathrm{CC}-3^{\prime}$ in $25 \mu \mathrm{l}$ volume consisting of $1 \mu \mathrm{l}$ of the diluted PCR product and the same concentration of the other parameters as for the first PCR. The amplification programme was the same except for the annealing temperature, which was at $65^{\circ} \mathrm{C}$.

To confirm the result obtained by colony blotting, PCR was performed on extracted bacterial DNA to amplify the 16S rRNA gene and the gyrB gene of Vibrio aestuarianus using the same programme as before, with $300 \mathrm{ng}$ and $500 \mathrm{ng}$ of chromosomal DNA for $16 \mathrm{~S}$ rDNA PCR and gyrB PCR, respectively.

Cloning and sequencing of $16 \mathrm{~S}$ rRNA gene. To confirm the specific PCR results, 16S rRNA genes of the 3 colonies isolates from sediment $(07 / 058,07 / 059$, and 07/061) and one of those isolated from the oyster haemolymph (07/118) were amplified using the universal eubacterial primers E8F and 1492R. The amplified products were cloned into the PCR II plasmids using the TA Cloning Kit (Fisher Scientific) according to the manufacturer's instructions. Three clones per strain were chosen for sequencing. The sequencing was performed by the genomic service company COGENICS $^{\mathrm{TM}}$. Sequences were compared to the GenBank database using online software and the basic local alignment search tool algorithm (BLAST) (Altschul et al. 1997).

Statistical analysis. Analysis of the results and trends in Vibrio aestuarianus occurrence in sediment and haemolymph samples, with respect to changes in the physicochemical parameters of water (e.g. temperature, salinity, and $\mathrm{pH}$ ) was carried out using Microsoft Excel and STRATGRAPHICS Plus software, version 5.1. Bacterial concentrations were log transformed for 1-way ANOVA and multiple regression analysis, using temperature, salinity, and $\mathrm{pH}$ values.

\section{RESULTS}

\section{Seasonal abundance of total cultured heterotrophic bacteria, TCBS agar Vibrio, and $V$. aestuarianus populations}

The culturable counts of heterotrophic bacteria (HB) TCBS agar Vibrio (TV), and V. aestuarianus-like bacteria detected by colony blot (Vaest) were performed over 2 years in 2 oyster farms in Aber Benoît (Fig. 2) and Rivière d'Auray (Fig. 3). Bacterial counts in sediment samples under and away from the tables were not significantly different. Analyses were then conducted using the combined values. HB, TV, and Vaest showed similar seasonal trends, with highest concentrations during the summer months. The HB counts fluctuated between $3 \times 10^{4}$ and $1 \times 10^{8} \mathrm{CFU} \mathrm{ml}^{-1}$ in haemolymph, and between $1 \times 10^{4}$ and $3 \times 10^{6} \mathrm{CFU} \mathrm{g}^{-1}$ in sediment in Aber Benoît. At Rivière d'Auray their concentrations varied between $6 \times 10^{3}$ and $4 \times 10^{6} \mathrm{CFU}$ $\mathrm{ml}^{-1}$ in haemolymph, while they ranged from $5 \times 10^{4}$ to $6 \times 10^{6} \mathrm{CFU} \mathrm{g}^{-1}$ in the sediment.

Throughout the survey, TV were detected both in sediment and in haemolymph of oysters in both areas. At Rivière d'Auray, their counts were about $1 \times 10^{2}$ to $3 \times 10^{4} \mathrm{CFU} \mathrm{ml} \mathrm{m}^{-1}$ in the haemolymph, with the highest concentrations in July and August 2007 (water temperature 19 to $22^{\circ} \mathrm{C}$ ). In sediment samples the counts were about $2 \times 10^{3}$ to $1 \times 10^{5} \mathrm{CFU} \mathrm{g}^{-1}$, with the highest counts
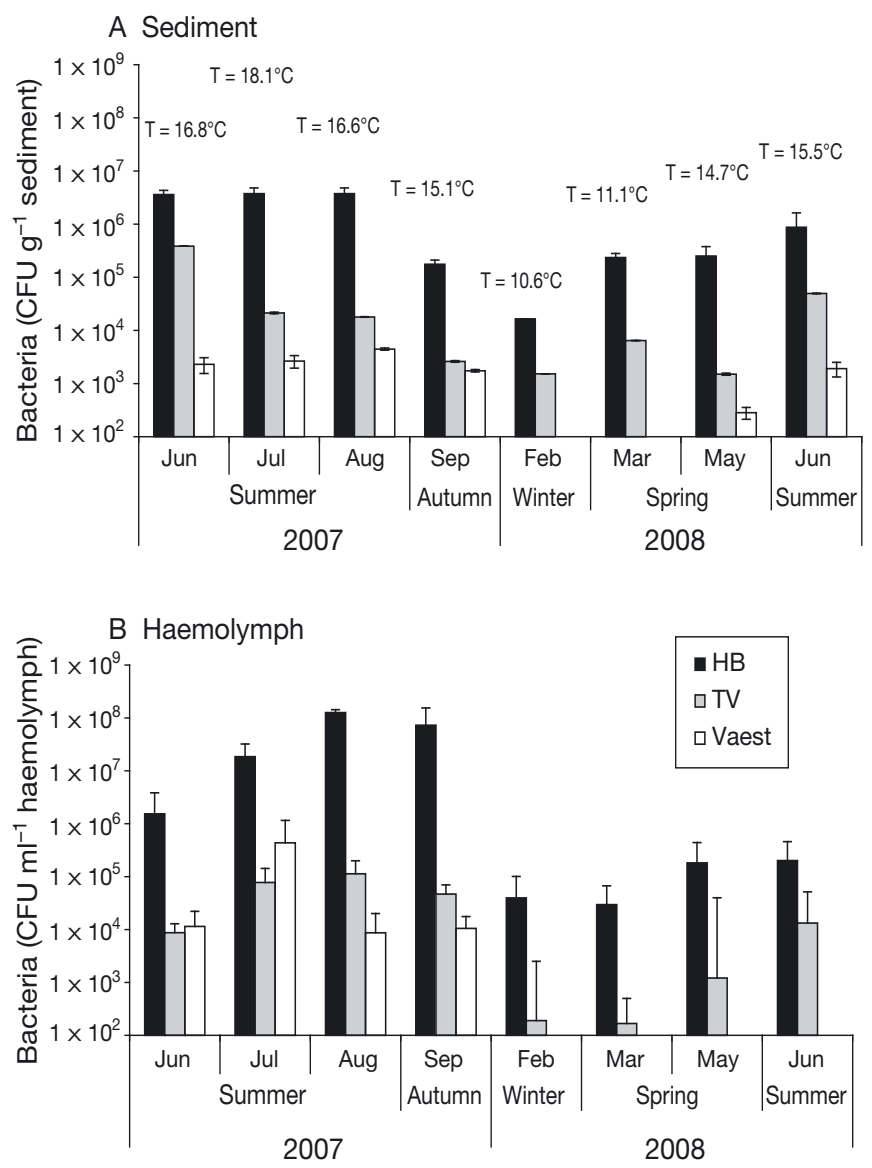

Fig. 2. Culturable heterotrophic bacteria (HB), TCBS (thiosulfate citrate bile salt sugar) agar Vibrio (TV) and $V$. aestuarianus (Vaest) in (A) sediment and (B) haemolymph of oysters in Aber-Benoît over time. Water temperature ( $\mathrm{T}$ ) on sampling dates is shown 

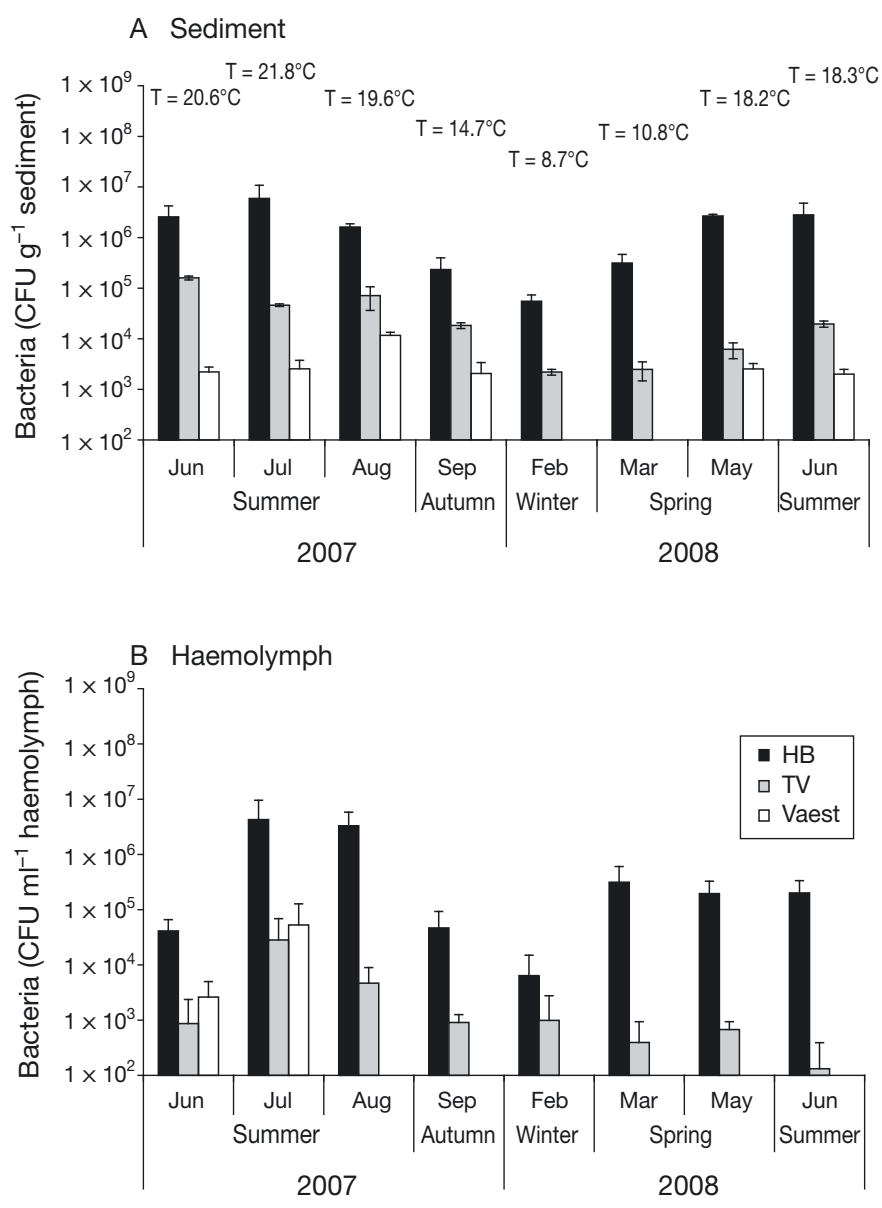

Fig. 3. Culturable heterotrophic bacteria (HB), TCBS (thiosulfate citrate bile salt sugar) agar Vibrio (TV) and $V$. aestuarianus (Vaest) in (A) sediment and (B) haemolymph of oysters in Rivière d'Auray over time. Water temperature $(\mathrm{T})$ on sampling dates is shown

in June to August. In June 2008 the TV counts in oyster haemolymph and in sediment fell by 1 log. The proportion of TV in relation to $\mathrm{HB}$ in the sediment ranged from $0.1 \%$ in February 2008 to $10 \%$ in June 2007. In the haemolymph its relative percentage varied between $0.01 \%$ in June 2008 and $1 \%$ in June 2007 .

TV concentrations were typically higher in Aber Benoît, and ranged from $2 \times 10^{3}$ to $1 \times 10^{5} \mathrm{CFU} \mathrm{ml}^{-1}$ in haemolymph and from $1 \times 10^{3}$ to $3 \times 10^{6} \mathrm{CFU} \mathrm{g}^{-1}$ in sediment. As in Rivière d'Auray, the TV counts were higher in the summer period in both sampling sites, with the highest concentrations observed in June 2007 for sediment and in June to August for the haemolymph. The lowest occurrence of TV in haemolymph was observed in February and March 2008. The percent of TV fluctuated within the same range as in Rivière d'Auray.

Similar to TV populations, Vaest was subject to the same seasonal fluctuations. In Rivière d'Auray, it was detected in the summer of 2007 in sediment and haemolymph. In the sediment, concentrations ranged between below the limit of detection $\left(10^{3} \mathrm{CFU} \mathrm{g}^{-1}\right)$ and $1 \times 10^{4} \mathrm{CFU} \mathrm{g}^{-1}$. In haemolymph it occurred only in June and July at concentrations of $2 \times 10^{3} \mathrm{CFU} \mathrm{ml^{-1 }}$ and $5 \times 10^{4} \mathrm{CFU} \mathrm{ml^{-1 }}$, respectively, while it remained countable in the sediment until September. No Vaest was detected in February and March 2008 in either site. Vaest appeared again in May and June 2008 in sediment but not yet in haemolymph.

In Aber Benoît, the Vaest concentrations in sediment were about $10^{3} \mathrm{CFU} \mathrm{g}^{-1}$ from June to September 2007 , and in May and June 2008. As in Rivière d'Auray, it was not possible to detect Vaest either in the sediment or in the haemolymph in February and March 2008. Its concentration in haemolymph in June, to September 2007 varied between $8 \times 10^{3} \mathrm{CFU} \mathrm{ml}^{-1}$ and $4 \times 10^{5} \mathrm{CFU}$ $\mathrm{ml}^{-1}$, with the highest values recorded in July when it exceeded the TV counts, as in Rivière d'Auray. In May and June 2008 Vaest was not detected in the haemolymph, while the sediment samples harboured a concentration of $10^{2} \mathrm{CFU} \mathrm{g}^{-1}$. The proportion of Vaest in relation to TV and $\mathrm{HB}$ varied enormously in the haemolymph and sediment of both locations and was about $1 \%$ of HB in July.

\section{Physico-chemical parameters}

Vaest cultured counts in sediment and haemolymph of oysters were compared with environmental parameters such as temperature, salinity, and $\mathrm{pH}$ of the water column. In Rivière d'Auray a higher salinity was observed from June to September (30 to 35) in comparison with February, March and May (22 to 27). The water pH ranged between 8 and 8.60, with the lowest value for August 2007. In Aber Benoît, the salinity did not vary greatly between spring, autumn, and summer months, ranging between 32 and 33. The water temperature in Aber Benoît varied between 15 and $18^{\circ} \mathrm{C}$ during the spring, autumn, and summer seasons and never reached $20^{\circ} \mathrm{C}$ during summer (Figs. $2 \& 3$ ). The $\mathrm{pH}$ was maintained around 7.9 \pm 0.1 . We used multiple regression analysis to compare $\log _{10}$ cultured TV and $\log _{10}$ cultured Vaest abundance with environmental parameters.

A moderate positive relationship was observed between $\log _{10}$ cultured Vaest concentrations in haemolymph and the water temperature. Correlation coefficients for the Aber Benoît and Rivière d'Auray sites, respectively, were $0.6972(\mathrm{p}<0.001)$ and $0.5083(\mathrm{p}=$ 0.0548 ) (Table 1). When considering semi-partial correlation, this parameter explained about 89 and $76 \%$ of the variability of cultured Vaest counts, respectively.

There was also a relationship between temperature and the sediment Vaest concentrations at both sites. 
The correlation coefficients were $0.68(\mathrm{p}<0.0032)$ for Aber Benoît and 0.3785 ( $\mathrm{p}<0.0047$ ) for the Rivière d'Auray. The influence of temperature on sediment samples could reach 99\% in Aber Benoît and 95\% in the Rivière d'Auray.

Salinity and $\mathrm{pH}$ were much weaker factors than temperature in determining the prevalence of Vaest at both sites. Indeed, we observed no significant correlation between salinity with $\log _{10}$ cultured Vaest abundance, neither in haemolymph nor in the sediment of both sites. Nevertheless, a moderate, but negative correlation was found, as shown by the correlation coefficients in Table 1 between $\mathrm{pH}$ and Vaest counts either in haemolymph or in the sediment.

The $\log _{10}$ TV counts in haemolymph and sediment were positively correlated in Aber Benoît to water temperature, while in the Rivière d'Auray its influence was nominal (Table 2). When considering semi-partial correlation, this parameter explained about 43 and $58 \%$ of cultured TV counts in haemolymph and sediment, respectively.

\section{PCR with Vibrio aestuarianus 16S RNA gene specific primers}

Nested PCR was used to detect the presence of Vibrio aestuarianus in the sediment at Aber-Benoît and Rivière d'Auray. The results showed that the oyster table sediments, as the control sediments, were positive for both the Aber Benoît and Rivière d'Auray sites.
The intensities of the bands were almost identical in Rivière d'Auray, while there were some variations in Aber Benoît.

\section{Identification of isolated Vibrio aestuarianus strains}

The colonies detected on marine agar by colony blotting were very small when originating from sediment, while they were bigger when originating from haemolymph. Although Vaest detection, performed by our species-specific probe via colony-hybridization, allowed culturable strains of this bacterium to be quantified, it was difficult to isolate it from the marine agar plate when cultures were made from sediment samples. Indeed, after the membrane transfer to marine agar, the colonies spread out on the agar medium and the larger ones sometimes covered the smallest ones. Thus, it became difficult to find Vaest colonies when they were very small in number. Nevertheless, a total of 21 strains resembling Vaest colonies were isolated on marine agar from Aber Benoît. Among these strains, 3 came from sediment and 18 from haemolymph. The DNA was later extracted and the partial sequences of 16S rRNA and gyrB genes were amplified with Vibro aestuarianus-specific primers. The affiliation of strains from haemolymph and sediment to $V$. aestuarianus was confirmed. Indeed the 2 types of PCR were positive for all of the 18 oyster and the 3 sediment strains. To confirm this result, the $16 \mathrm{~S}$ rRNA gene of the 3

Table 1. Results of multiple regression analysis of $\log _{10}$ cultural Vibrio aestuarianus counts in haemolymph and sediment versus environmental parameters at Aber-Benoît (AB) and Rivière d'Auray (RA)

\begin{tabular}{|c|c|c|c|c|c|c|}
\hline \multirow{2}{*}{ Independent variable } & \multicolumn{2}{|c|}{ —Regression coefficient - } & \multicolumn{2}{|c|}{ Square semi-partial correlation (\%) } & \multirow{2}{*}{$\overline{\text { Haemolymph }}$} & \multirow[b]{2}{*}{ Sediment } \\
\hline & Haemolymph & Sediment & Haemolymph & Sediment & & \\
\hline Temperature AB & 0.6972 & 0.6823 & 89 & 99 & $<0.001$ & 0.0032 \\
\hline Salinity AB & -0.1914 & -0.1914 & 2.255 & 0.03 & 0.0726 & 0.8129 \\
\hline $\mathrm{pH} \mathrm{AB}$ & -0.9971 & -0.9971 & 8.699 & 0.761 & 0.0684 & 0.8849 \\
\hline Temperature RA & 0.5083 & 0.3785 & 76.13 & 95.52 & 0.0548 & 0.0047 \\
\hline Salinity RA & -0.5084 & -0.5067 & 7.973 & 0.215 & 0.5837 & 0.8002 \\
\hline pH RA & -0.9833 & -0.9902 & 1.097 & 4.433 & 0.4660 & 0.2867 \\
\hline
\end{tabular}

Table 2. Results of multiple regression analysis of $\log _{10}$ cultured Vibrio spp. counts in haemolymph and sediment versus environmental parameters at Aber-Benoît (AB) and Rivière d'Auray (RA)

\begin{tabular}{|c|c|c|c|c|c|c|}
\hline \multirow{2}{*}{ Independent variable } & \multicolumn{2}{|c|}{ — Regression coefficient - } & \multicolumn{2}{|c|}{ Square semi-partial correlation (\%) } & \multirow{2}{*}{$\overline{\text { Haemolymph }}$} & \multirow[b]{2}{*}{ Sediment } \\
\hline & Haemolymph & Sediment & Haemolymph & Sediment & & \\
\hline Temperature AB & 0.6972 & 0.6972 & 93.80 & 91 & $<0.001$ & 0.2058 \\
\hline Salinity AB & -0.1994 & -0.1194 & 0.24 & 8.90 & 0.8275 & 0.6601 \\
\hline pH AB & -0.9971 & -0.9971 & 5.95 & 0.003 & 0.3074 & 0.993 \\
\hline Temperature RA & 0.4015 & 0.4015 & 43.08 & 57.53 & 0.3247 & 0.0851 \\
\hline Salinity RA & -0.5013 & -0.5013 & 9.50 & 12.38 & 0.6261 & 0.3504 \\
\hline pH RA & -0.9958 & -0.9958 & 47.43 & 30.10 & 0.3043 & 0.8453 \\
\hline
\end{tabular}


strains isolated from sediment, 07/058, 07/059, 07/061, and 1 strain from haemolymph (07/118), was cloned and sequenced. The 07/058, 07/061, and 07/118 sequences presented $100 \%$ homology with V. aestuarianus sp. francencis (AJ845014), while the 07/059 sequence presented $99 \%$ homology with the same strain.

\section{DISCUSSION}

Here we used an oligonucleotide hybridization with the gyrB gene probe to detect and quantify cultured Vibrio aestuarianus in Crassostrea gigas haemolymph and sediment samples at 2 estuarine sites in France. The colonies detected by this method undoubtedly belonged to $V$. aestuarianus. The sensitivity of this method depended on the proportion of $V$. aestuarianus in the total culturable bacterial population. The threshold was $10^{3} \mathrm{CFU} \mathrm{g}{ }^{-1}$ in sediment over the year and $10^{3} \mathrm{CFU} \mathrm{ml} \mathrm{m}^{-1}$ in haemolymph in the summer and $10^{2}$ in winter. The drop in Vibrio populations and the absence of $V$. aestuarianus during winter were consistent with other studies which showed that Vibrio concentrations could fall dramatically in winter (Thompson et al. 2004). For example, the levels of $V$. vulnificus, $V$. cholera, and $V$. parahaemolyticus were much lower in winter than in summer or often undetectable (Ayres \& Barrow 1978, Oliver et al. 1983, O'Neill et al. 1992). Nevertheless, Fukushima \& Seki (2004) recovered V. vulnificus and $V$. parahaemolyticus from the sediment and water of coastal and brackish environments, respectively, using the most probable number count method. Thus the detection and recovery of a bacterium depend not only on the environmental conditions, but also on the method used. The lower temperatures may be incriminated in this disappearance. Indeed, as shown by the estimated regression coefficient in a linear multiple regression using environmental parameters, $V$. aestuarianus as well as TCBS agar Vibrio spp. counts in sediment were positively correlated with water temperature, which appeared to greatly influence culturable bacterial concentrations. A similar influence was previously reported by Parveen et al. (2008) for $V$. parahaemolyticus, with a high correlation coefficient for temperature, which explained $68 \%$ of the variation of this species. Thus, the HB, TV, and Vaest concentrations in the sediment of both sites were similar during the spring and summer months, while temperatures were on average $1.5^{\circ} \mathrm{C}$ higher in Rivière d'Auray. At Aber Benoît, they were at least $10 \times$ greater in haemolymph during June to August 2007 in comparison to Rivière d'Auray.

Previous studies have demonstrated that salinity highly influences the dynamics and physiology of several Vibrio spp. (Soto et al. 2009). A positive correlation between Vibrio spp. and seasonal salinity has been shown by several authors (Hsieh et al. 2004, Fries et al. 2008, Hsieh et al. 2008), although other authors have found temperature to be a more important factor (Pfeffer et al. 2003). For example, with $V$. parahaemolyticus, Parveen et al. (2008) found a significant relationship between salinity and counts of this bacterium, while other studies did not (Ristori et al. 2007). As noted by Ristori et al. (2007), this may have resulted from the difference in the range of observed salinity levels. The tolerance to salinity of the Vibrio spp. under consideration must also be taken into account.

In the present study no correlation was found between $\mathrm{pH}$ and the Vibrio spp. concentrations, probably because the variation in $\mathrm{pH}$ was too weak ( 7.5 to $8)$. The fact that $V$. aestuarianus was absent in sediment in February and March may be explained by low temperature, so that the concentration of the remaining cells was below the limit of detection $\left(10^{3} \mathrm{CFU} \mathrm{g}^{-1}\right.$ dry sediment). However, using specific PCR, V. aestuarianus was detected in the sediment samples of the 2 sites in March when the temperature remained low, even though their intensity levels were lower than in the June samples. These results suggest that $V$. aestuarianus is a permanent resident of both areas. One possible reason why they could not be cultured is that Vibrio spp. can enter into a viable but non-culturable (VBNC) state in response to environmental stresses, including nutrients depletion, $\mathrm{pH}$, salinity, and low temperature (Oliver 1995, Jiang \& Chai 1996, Du et al. 2007, Amel et al. 2008, Chen et al. 2009, Zhong et al. 2009). The seasonality observed in culturable concentrations of $V$. aestuarianus in sediment suggests that this bacterium could survive in the sediment in a VBNC state when the environmental conditions are unfavourable and rise again under favourable conditions. The persistence of Vibrio spp. in the environment is also backed by their relationship with benthic and plankton populations. Indeed, Vibrio spp. living in marine and estuarine environments can survive by attaching to and using the chitin exoskeleton of benthic and planktonic crustaceans such as copepods (Pruzzo et al. 1996, Bhowmick et al. 2007, Rawlings et al. 2007, Gugliandolo et al. 2008, Harriague et al. 2008, Seeligmann et al. 2008, Vezzulli et al. 2008). It has not yet been demonstrated that $V$. aestuarianus binds to plankton; however, analyses of its genome confirms the presence of chitinase genes (data not shown), which suggests some relationship with crustaceans.

After August, Vibrio populations decreased and $V$. aestuarianus was no longer detected in haemolymph in Rivière d'Auray, while the sediment still harboured populations at a level of $10^{3}$ to $10^{4} \mathrm{CFU} \mathrm{g}^{-1}$. Therefore, it is likely that another factors other than temperature could affect the occurrence of this bacterium in haem- 
olymph. Its persistence depends also on the immune and physiological status of Crassostrea gigas. Gametogenesis induces profound modifications in the haemocyte parameters of bivalves (Cheng 2000, Chu 2000), and oysters seem to be more sensitive to infection during this period (Samain \& McCombie 2008). Therefore the absence of $V$. aestuarianus and the decrease in Vibrio populations in the haemolymph of oysters could be due to the immune system of $C$. gigas recovering after spawning, which occurred in July 2007 in Rivière d'Auray, but never in Aber Benoît.

In any case, not all bacteria presented in water can penetrate, grow, and thrive in molluscs (Beleneva \& Zhukova 2006), even if the haemolymph of Pacific oysters is particularly permeable to bacteria. The penetration and persistence of bacteria in their hosts may depend on the presence of some specific genes in the bacteria. For example, Paranjpye et al. (2007) showed that pilA-encoded type IV pili were involved in the persistence of Vibrio vulnificus in oysters and served in opportunistic infections. A type IV mannose-sensitive haemagglutinin (MSHA)-like pilus promotes and increases the presence of $V$. cholerae El Tor strains in bivalve hosts (Pruzzo et al. 2005). Analysis of the genome sequence of $V$. aestuarianus revealed that it possessed the MSHA-like gene (data not shown).

In conclusion, our hybridisation method allowed Vibrio aestuarianus strains to be detected and quantified in sediment and the haemolymph of oysters from 2 French oyster farms in Brittany. We showed a seasonal trend in both sites, correlated mainly with temperature. In haemolymph, the presence of $V$. aestuarianus could be affected by the immune status of the oysters. Interestingly, even when present in high concentrations (up to $10^{5} \mathrm{ml}^{-1}$ ) in haemolymph, this bacterium did not induce mortality. This feature proves the capacity of oysters to tolerate and to control $V$. aestuarianus, among other bacteria, in order to avoid becoming infected.

This study highlights several questions that may need further investigation. In vitro experiments to verify the ability of Vibrio aestuarianus to enter a VBNC state, its ability to use chitin and further environmental investigations integrating water, phytoplankton, and copepods would be necessary to create a circulation model between different biotopes. In addition, a gene typing method should be developed to find out if the $V$. aestuarianus strains in sediment and oysters are identical or not. A previous study (M. Garnier unpubl.) demonstrated the species specificity of the gyrB probe when tested against Vibrio and V. aestuarianus collection. Unfortunately, at the moment no specific virulence marker is available for $V$. aestuarianus and pathogenic strains detection is thereby not possible. Previous studies on vam gene detection were unsuccessful because it was present in the genome of every strain of $V$. aestuarianus tested. However, research is planned to identify a virulence marker to allow development of a PCR method to discriminate pathogens strains from non-pathogenic. That should permit to estimate the real risk of sediment due to the presence of $V$. aestuarianus.

Acknowledgements. This work was supported by Brittany Region and the French Research Institute for Exploitation of the Sea (IFREMER). We are grateful to Marie-Josée Garet Delmas and Agnes Youenou for their technical assistance.

\section{LITERATURE CITED}

Altschul SF, Madden TL, Schaffer AA, Zhang JH, Zhang Z, Miller W, Lipman DJ (1997) Gapped BLAST and PSIBLAST: a new generation of protein database search programs. Nucleic Acids Res 25:3389-3402

Amel BKN, Amine B, Amina B (2008) Survival of Vibrio fluvialis in seawater under starvation conditions. Microbiol Res 163:323-328

Ayres PA, Barrow GI (1978) Distribution of Vibrio parahaemolyticus in British coastal waters - report of a collaborative study 1975-1976. J Hyg (Lond) 80:281-294

Beleneva IA, Zhukova NV (2006) Bacterial communities of some brown and red algae from Peter the Great Bay, the Sea of Japan. Microbiology 75:348-357

> Bhowmick R, Ghosal A, Chatterjee NS (2007) Effect of environmental factors on expression and activity of chitinase genes of vibrios with special reference to Vibrio cholerae. J Appl Microbiol 103:97-108

Chen SY, Jane WN, Chen YS, Wong HC (2009) Morphological changes of Vibrio parahaemolyticus under cold and starvation stresses. Int J Food Microbiol 129:157-165

Cheng TC (2000) Cellular defense mechanisms in oysters. In: Fingerman M NRe (ed) Recent advances in marine bitechnology: immunobiology and pathology. Sciences Publishers, Enfield, NH, p 43-83

Chu FLE (2000) Defense mechanism of marine bivalves. In: Fingerman M NRe (ed) Recent advances in marine biotechnology: immunobiology and pathology. Sciences Publishers, Enfield, NH, p 1-42

$>$ Du M, Chen JX, Zhang XH, Li AJ, Li Y (2007) Characterization and resuscitation of viable but nonculturable Vibrio alginolyticus VIB283. Arch Microbiol 188:283-288

Eiler A, Bertilsson S (2006) Detection and quantification of Vibrio populations using denaturant gradient gel electrophoresis. J Microbiol Methods 67:339-348

> Eiler A, Gonzalez-Rey C, Allen S, Bertilsson S (2007) Growth response of Vibrio cholerae and other Vibrio spp. to cyanobacterial dissolved organic matter and temperature in brackish water. FEMS Microbiol Ecol 60:411-418

Fries JS, Characklis GW, Noble RT (2008) Sediment-water exchange of Vibrio sp. and fecal indicator bacteria: implications for persistence and transport in the Neuse river estuary, North Carolina, USA. Water Res 42:941-950

Fukushima H, Seki R (2004) Ecology of Vibrio vulnificus and Vibrio parahaemolyticus in brackish environments of the Sada River in Shimane Prefecture, Japan. FEMS Microbiol Ecol 48:221-229

> Garnier M, Labreuche Y, Garcia C, Robert A, Nicolas JL (2007) Evidence for the involvement of pathogenic bacteria in summer mortalities of the Pacific oyster Crassostrea gigas. Microb Ecol 53:187-196 
Garnier M, Labreuche Y, Nicolas JL (2008) Molecular and phenotypic characterization of Vibrio aestuarianus subsp francensis subsp nov., a pathogen of the oyster Crassostrea gigas. Syst Appl Microbiol 31:358-365

Gugliandolo C, Irrera GP, Lentini V, Maugeri TL (2008) Pathogenic Vibrio, Aeromonas and Arcobacter spp. associated with copepods in the Straits of Messina (Italy). Mar Pollut Bull 56:600-606

Harriague AC, Di Brino M, Zampini M, Albertelli G, Pruzzo C, Misic C (2008) Vibrio in association with sedimentary crustaceans in three beaches of the northern Adriatic Sea (Italy). Mar Pollut Bull 56:574-579

Hsieh JL, Fries JS, Noble RT (2004) Vibrio and phytoplankton dynamics during the summer of 2004 in a eutrophying estuary. Conf Eutroph Path Impact New Jers Coast Bay S102-S109

Hsieh JL, Fries JS, Noble RT (2008) Dynamics and predictive modelling of Vibrio spp. in the Neuse river estuary, North Carolina, USA. Environ Microbiol 10:57-64

Jiang XP, Chai TJ (1996) Survival of Vibrio parahaemolyticus at low temperatures under starvation conditions and subsequent resuscitation of viable, nonculturable cells. Appl Environ Microbiol 62:1300-1305

Labreuche Y, Soudant P, Goncalves M, Lambert C, Nicolas JL (2006) Effects of extracellular products from the pathogenic Vibrio aestuarianus strain $01 / 32$ on lethality and cellular immune responses of the oyster Crassostrea gigas. Dev Comp Immunol 30:367-379

O'Neill KR, Jones SH, Grimes DJ (1992) Seasonal incidence of Vibrio vulnificus in the Breat Bay estuary of New Hampshire and Maine. Appl Environ Microbiol 58:3257-3262

Oliver JD (1995) The viable but non-culturable state in the human pathogen Vibrio vulnificus. FEMS Microbiol Lett 133:203-208

Oliver JD, Warner RA, Cleland DR (1983) Distribution of Vibrio vulnificus and other lactose-fermenting vibrios in the marine. Appl Environ Microbiol 45:985-998

Paranjpye RN, Johnson AB, Baxter AE, Strom MS (2007) Role of type IV pilins in persistence of Vibrio vulnificus in Crassostrea virginica oysters. Appl Environ Microbiol 73: 5041-5044

Parveen S, Hettiarachchi KA, Bowers JC, Jones JL and others (2008) Seasonal distribution of total and pathogenic Vibrio parahaemolyticus in Chesapeake Bay oysters and waters. Int J Food Microbiol 128:354-361

Pfeffer CS, Hite MF, Oliver JD (2003) Ecology of Vibrio vulnificus in estuarine waters of eastern North Carolina. Appl Environ Microbiol 69:3526-3531

Editorial responsibility: Stephen Feist, Weymouth, UK
Pruzzo C, Crippa A, Bertone S, Pane L, Carli A (1996) Attachment of Vibrio alginolyticus to chitin mediated by chitinbinding proteins. Microbiol UK 142:2181-2186

> Pruzzo C, Gallo G, Canesi L (2005) Persistence of vibrios in marine bivalves: the role of interactions with haemolymph components. Environ Microbiol 7:761-772

> Rawlings TK, Ruiz GM, Colwell RR (2007) Association of Vibrio cholerae O1 El Tor and O139 Bengal with the copepods Acartia tonsa and Eurytemora affinis. Appl Environ Microbiol 73:7926-7933

Ristori CA, Iaria ST, Gelli DS, Rivera ING (2007) Pathogenic bacteria associated with oysters (Crassostrea brasiliana) and estuarine water along the south coast of Brazil. Int J Environ Health Res 17:259-269

Samain JF, McCombie H (2008) Summer mortality of Pacific oyster Crassostrea gigas: The Morest Project. Éditions Quae, Versailles

Seeligmann CT, Mirande V, Tracanna BC, Silva C, Aulet O, Cecilia M, Binsztein N (2008) Phytoplankton-linked viable non-culturable Vibrio cholerae O1 (VNC) from rivers in Tucuman, Argentina. J Plankton Res 30:367-377

Soto W, Gutierrez J, Remmenga MD, Nishiguchi MK (2009) Salinity and temperature effects on physiological responses of Vibrio fischeri from diverse ecological niches. Microb Ecol 57:140-150

Thompson JR, Randa MA, Marcelino LA, Tomita-Mitchell A, Lim E, Polz MF (2004) Diversity and dynamics of a north Atlantic coastal Vibrio community. Appl Environ Microbiol 70:4103-4110

Vezzulli L, Pezzati E, Repetto B, Stauder M, Giusto G, Pruzzo C (2008) A general role for surface membrane proteins in attachment to chitin particles and copepods of environmental and clinical Vibrio. Lett Appl Microbiol 46: $119-125$

Weisburg WG, Barns SM, Pelletier DA, Lane DJ (1991) 16S Ribosomal DNA amplification for phylogenetic study. J Bacteriol 173:697-703

Wright AC, Miceli GA, Landry WL, Christy JB, Watkins WD, Morris JG (1993) Rapid identification of Vibrio vulnificus on nonselective media with an alkaline phosphataselabeled oligonucleotide probe. Appl Environ Microbiol 59:541-546

Zhong L, Chen J, Zhang XH, Jiang YA (2009) Entry of Vibrio cincinnatiensis into viable but nonculturable state and its resuscitation. Lett Appl Microbiol 48:247-252

Zhou JZ, Bruns MA, Tiedje JM (1996) DNA recovery from soils of diverse composition. Appl Environ Microbiol 62: $316-322$

Submitted: January 21, 2010; Accepted: June 14, 2010 Proofs received from author(s): August 24, 2010 